\title{
Study on the effectiveness of pragmatic transfer in third language acquisition
}

\author{
Yu Chunyan
}

\author{
Nanchang Institute of Science \& Technology, Nanchang 330108,China
}

\begin{abstract}
Key words: third language acquisition; Uygur; pragmatic transfer; English learning; group teaching
\end{abstract}

\begin{abstract}
As a result of the Uygur language has been the mother tongue and the first language, if Chinese is the second language, then English becomes the third language, and the interaction between the three language acquisition is more complex. In this context, combined the relationship between the three language acquisition, this paper proposes an innovative approach to English teaching based on pragmatic transfer. In the process of teaching experiment by using the method of group teaching, according to the three language acquisition of pragmatic transfer, the teaching group is divided into the improvement of teaching methods and traditional teaching methods, and in accordance with a certain proportion, the teaching tasks are assigned and the teaching objectives are established. Finally, through the overall score and analysis of teaching effect, after the improvement of English teaching methods using the three language pragmatic transfer, we found that the teaching effect has been significantly improved, especially in spoken English, grammar, students' grades have improved, which proves the teaching effect of the promoting effect of three language acquisition of pragmatic transfer.
\end{abstract}

\section{Introduction}

English teaching is a basic language teaching, if teaching methods followed the traditional teaching mode, it will make the English classroom atmosphere inactive, and the students' thinking style not innovative, students cannot learn English by rote learning this course. It is the focus of the new teaching reform how to liven the classroom atmosphere, innovate the teaching methods and develop the students' thinking. This paper presents a new approach to English teaching in the light of the characteristics of the three language acquisition. In the new teaching method, we focus on the role of the three language acquisition of third language learning, by promoting positive transfer and avoiding negative transfer, to further improve the English learning effect, which has an important significance for the study on the teaching method of minority language.

\section{Third Language Acquisition and Language Transfer}

In the Uygur region, most students will learn their native language in Uygur and Chinese language, if learning English, they will appear in three language acquisition. In many western countries, the study of the three language has been started, and some achievements have been obtained through the study. Some of the features of the acquisition of the three language and the main research results are summarized into the following 4 points.

(1) Language learning and ability improvement is a gradual process. When the second language acquisition has an impact on the process, it is generally regarded as a linear influence, of course, some stages will also accelerate or slow down the process of nonlinear dynamic change. 
(2) Any language in the three language will be forgotten if it is not used frequently, so the language needs to be maintained in the learning process, which is also a very important feature of the three language acquisition.

(3) The third language acquisition is more complicated than the acquisition of the second language in the process of English language learning, because the third language acquisition is influenced by many factors, the interaction between the three languages will lead to positive transfer and negative transfer of English language learning, therefore, it is necessary to use positive transfer to overcome the negative transfer in the learning process.

(4) The three languages of the three language acquisition is a complete system, so the three languages are not a simple sum of numbers, but there is a very large correlation between each language.

According to the characteristics of the three language acquisition, it is necessary to consider the relationship between the three languages in the process of English teaching. Through the reform of teaching methods and teaching models, the relationship between the three languages can be promoted, and the obstacles between the three languages can be eliminated.

\section{The Influence of Third Language Acquisition on English Learning}

There are 24 consonants and 21 vowels in English phonetics, while the modern Uygur language has a total of 32 letters, of which there are two vowels and 24 consonants, and the pronunciation of these two languages has a certain repeatability, therefore, native language has a positive effect on English language learning. In the aspect of the meaning of the word, the first and the second languages are different from the meaning of the English language. Therefore, it is a negative transfer to the English learning and should be overcome. In the aspect of grammar, because Chinese and English are the subject verb object structure, Uygur language structure using the subject object verb structure. Therefore, the Chinese language has a positive effect on the English grammar learning, and the Uygur language has a negative effect on English grammar learning, the interaction between them is shown in Fig. 1.

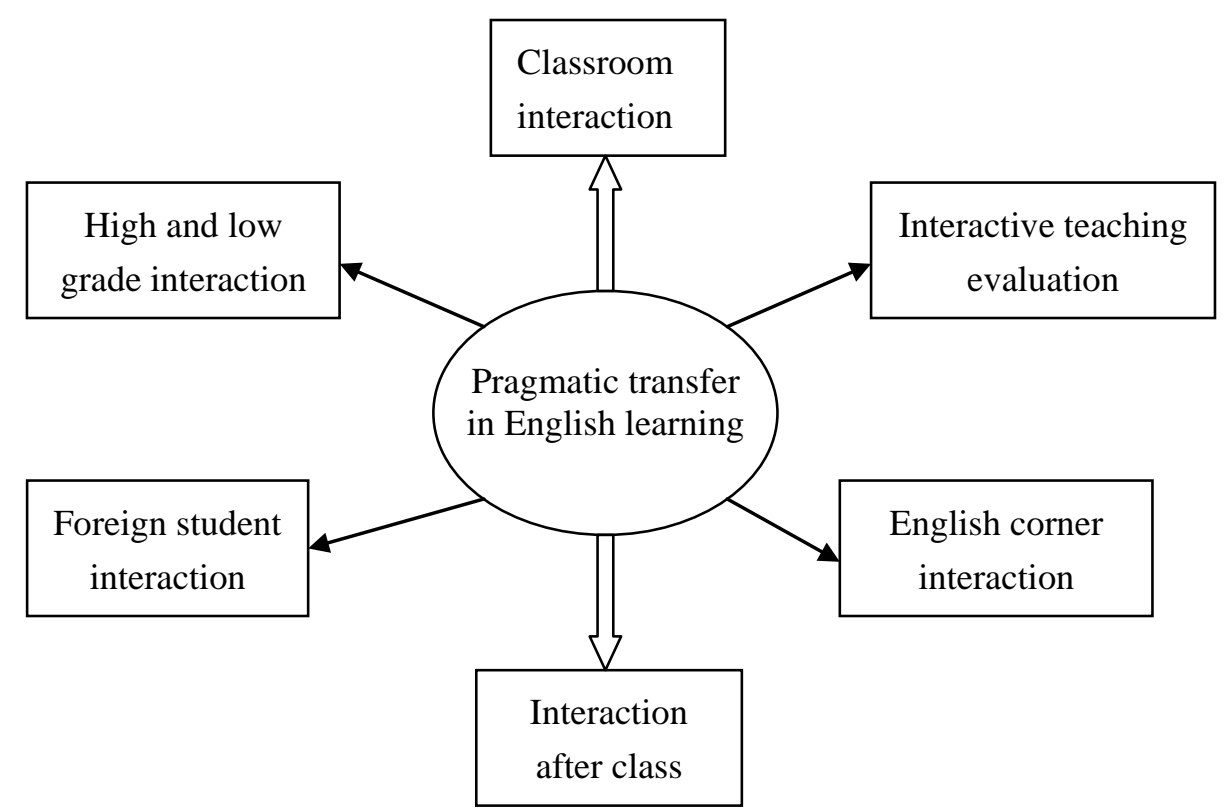

Fig. 1 The Pragmatic Transfer Model of English Learning

As shown in Figure 1, in the third language learners in the process of learning English, the influence of the first language and the second language on the third language is different, the 
relationship between the three languages is more complex, so in the process of English teaching needs to adopt related teaching means to promote the language of English and two positive transfer, try to avoid obstacles the role of the three language. In order to verify the effectiveness of the third language acquisition in the English Teaching of Uygur College students.

\section{Study on the Effectiveness of Pragmatic Transfer in College English Teaching}

According to the transfer of one and two language acquisition in English, in this study, we used the method of grouping teaching experiment, The orientation of the experimental group is mainly focused on the effect of the transfer of three language acquisition, through a certain teaching means to promote the positive transfer, to avoid the negative transfer. While the other group does not make any changes, assign the teaching task and specify the teaching goal to the teaching group first, as shown in table 1.

Tab. 1 the Specific Assignments of Teaching Tasks

\begin{tabular}{|c|c|c|}
\hline $\begin{array}{c}\text { English teaching } \\
\text { grouping }\end{array}$ & $\begin{array}{c}\text { Teaching task allocation } \\
\text { proportion }\end{array}$ & Teaching objectives \\
\hline Listening group & 0.3 & 72 \\
\hline Oral group & 0.3 & 81 \\
\hline Word group & 0.1 & 55 \\
\hline Grammar group & 0.3 & 75 \\
\hline
\end{tabular}

As shown in Table 1, according to the transfer function of the spoken language, meaning and grammar of English learning, according to a certain proportion of the allocation of the teaching task, and the development of the teaching goal, the meaning of the English learning effect, hinder, so assign fewer teaching tasks, the specified target is low.

Tab.2 The Whole Teaching Effect of Group Teaching

\begin{tabular}{|c|l|l|}
\hline $\begin{array}{l}\text { English teaching } \\
\text { grouping }\end{array}$ & $\begin{array}{c}\text { Variance before } \\
\text { teaching experiment }\end{array}$ & $\begin{array}{c}\text { Variance after } \\
\text { teaching experiment }\end{array}$ \\
\hline Listening group & 0.11 & 0.02 \\
\hline Oral group & 0.12 & 0.01 \\
\hline Word group & 0.10 & 0.05 \\
\hline Grammar group & 0.18 & 0.02 \\
\hline
\end{tabular}

We can see from table 2 that, the effect of the experimental group is significant after group teaching, the overall level of oral English has been improved, which were the biggest change, the biggest change is the oral group, listening and grammar group, meaning it was the worst, and the negative transfer of English learning effect. Among them, the change of the oral group was the largest, and the change of the hearing and grammar group was the second, the word group meaning is the worst, which is related to the negative transfer of English learning. 


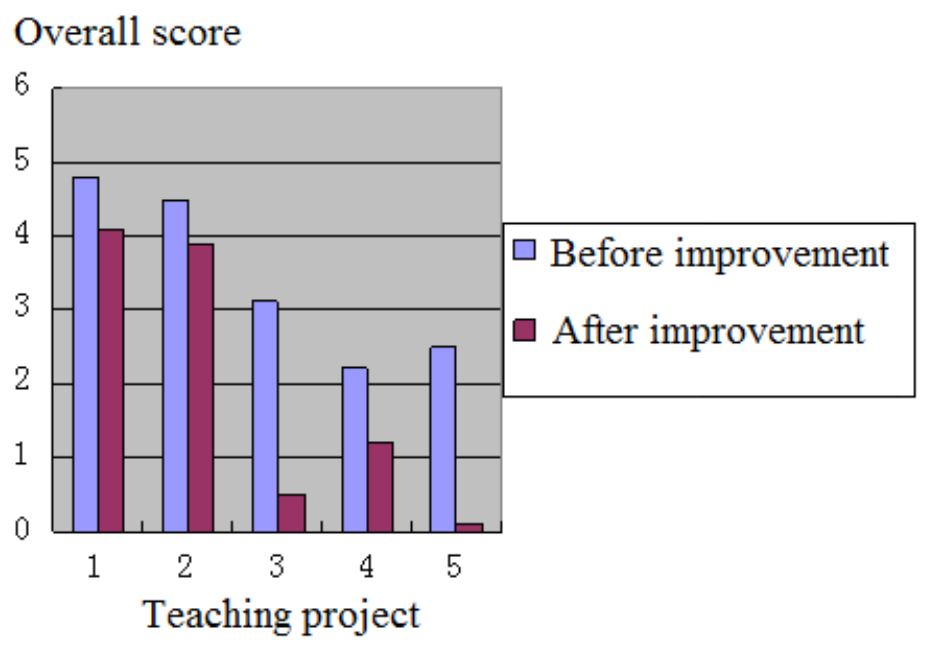

Fig. 2 Comparison of Teaching Effect

From the overall score of the teaching effect analysis table we can see that, the teaching method was improved by using the interaction between the three language acquisition, its teaching effect is obviously improved, which verifies the validity of Uygur students in English teaching third language acquisition of pragmatic transfer.

\section{Conclusion}

In order to explore the effectiveness of the thrird language acquisition in English teaching, the basic characteristics of the third language acquisition has been analyzed in the paper. And to a certain extent, the relationship between the third language has been promoted by the reform of teaching methods and teaching models, and the obstruction between the three languages can be eliminated, so as to effectively improve the effectiveness of English teaching. Based on the transfer of the first and second language acquisition of English, we have conducted a teaching experiment, it is found that the use of pragmatic transfer improves the experimental results, English learning achievement to enhance the rate of increase, especially in grammar and oral English, which verifies the validity of Uygur students in English teaching three language acquisition of pragmatic transfer.

\section{Acknowledgement}

The work was supported by the planning project, humanities and social science research project of universities and colleges in Jiangxi with the project number YY161007 and the project name Study on the Influence of Pragmatic Transfer in Third Language Acquisition on Uygur Students' English Speech Acts.

\section{Reference}

[1] Li Liwen. The study of English Autonomous Learning under multimedia network environment [J]. Journal of Teaching and Management, No.9, (2010), p.124-125.

[2] Ma Zongjuan. Problems and Countermeasures of autonomous learning in College English network platform [J]. Journal of Qinzhou University, No.6, (2009), p.54-57.

[3] Zhao Lingyun. Survey on College English Autonomous Learning in Hubei University of Economics [J]. Journal of Hubei University of Economics(Humanities and Social Sciences), No.11, (2011), p.197-198. 
[4] Zhang Yanhong. College English writing teaching dynamic evaluation mode of [J]. Foreign Language World, No.4, (2008), p.73-81.

[5] Zhang Yanhong. Study on the changing rules of non English Majors' English learning motivation [J]. China Education Innovation Herald, Vol. 25, (2008), p.107-108.

[6] Zhang Yanhong. Writing strategies for non English Majors [J]. Social Science Review, Vol. 24(8), (2009), p.172-173.

[7] Han Baocheng. Dynamic evaluation theory, model and its application in foreign language education [J]. Foreign Language Teaching and Research, Vol. 41(6), (2009), p.452-458.

[8] Zhang Yanhong. Dynamic evaluation system of College English writing teaching construction [J]. Journal of PLA University of Foreign Languages, Vol. 33 (1) , (2010), p.46-52.

[9] Zou Shen. A corpus based study on the test validity of writing: a case study of English writing teaching corpus [J]. foreign language teaching, No.1, (2012), p.16-21.

[10] Zhu Xiaohui. Study of language transfer in third language acquisition and its implications for the teaching of foreign languages. [J]. Journal of Guangdong University of Foreign Studies, No. 5 , (2008), p.109-112.

[11] Chen Baopeng, Hu Ailing. Stratified teaching model of higher education massification stage [J]. Journal of Liaoning Radio \& TV University, No.5, (2009), p.51-52

[12] Yang Yang. The advantages and disadvantages of multimedia teaching in English teaching [J]. Journal of Jilin TV \& Radio University, No.6, (2011), p.146-147.

[13] Zhang Yanhong. College English writing teaching dynamic evaluation mode of [J]. Foreign Language World, No.4, (2008), p.73-81.

[14] Wang Xiaoqin. Theory and practice of hierarchical teaching mode of advanced mathematics [J]. Jilin Education, No.11, (2009), p.20-21

[15] Mao Dahui. The implementation of higher vocational mathematics teaching [J]. Journal of Chongqing College of Electronic Engineering, Vol.16 (4) , (2007), p.43-44 